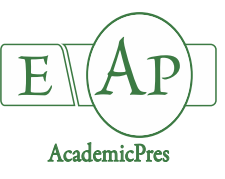

Dustgeer Z et al. (2021)

Notulae Botanicae Horti Agrobotanici Cluj-Napoca

Volume 49, Issue 1, Article number 12248

DOI: $10.15835 /$ nbha49112248

Research Article

\title{
Glycine-betaine induced salinity tolerance in maize by regulating the physiological attributes, antioxidant defense system and ionic homeostasis
}

\author{
Zain DUSTGEER ${ }^{1}$, Mahmoud F. SELEIMAN ${ }^{2,3 *}$, Imran KHAN ${ }^{4}$, \\ Muhammad U. CHATTHA ${ }^{4}$, Esmat F. ALI ${ }^{5}$, Bushra A. ALHAMMAD ${ }^{6}$, \\ Rewaa S. JALAL 7 , Yahya REFAY ${ }^{2}$, Muhammad U. HASSAN ${ }^{4}$ \\ ${ }^{1}$ University of Agriculture Faisalabad, Department of Botany, Faisalabad, 38040, Pakistan; zaindastgeer@gmail.com; \\ ${ }^{2}$ King Saud University, College of Food and Agriculture Sciences, Plant Production Department, P.O. Box 2460, Riyadh 11451, \\ SaudiArabia; mseleiman@ksu.edu.sa ("corresponding author); refay@ksu.edu.sa; \\ ${ }^{3}$ Menoufia University, Faculty of Agriculture, Department of Crop Sciences, Shibin El-kom 32514, Egypt \\ ${ }^{4}$ University of Agriculture Faisalabad, Department of Agronomy, Faisalabad, 38040, Pakistan; drimran@uaf.edu.pk; \\ drummer@uaf.edu.pk; muhassanuaf@gmail.com; \\ ${ }^{5}$ Taif University, College of Science, Department of Biology, P.O. Box 11099, Taif 21944, Saudi Arabia; a.esmat@tu.edu.sa; \\ ${ }^{6}$ Prince Sattam Bin Abdulaziz University, College of Science and Humanity Studies, Biology Department, Al Kharj Box 292, Riyadh \\ 11942, Saudi Arabia; b.alhammad@psau.edu.sa; \\ ${ }^{7}$ University of Jeddah, College of Sciences, Department of Biology, Jeddah, Saudi Arabia
}

\section{Abstract}

The plants are exposed to different abiotic stresses, including the salinity stress (SS) that negatively affect the growth, metabolism, physiological and biochemical processes. Thus, this study investigated the effect of diverse levels of foliar-applied GB (0 control, $50 \mathrm{mM}$ and $100 \mathrm{mM})$ on maize growth, membrane stability, physiological and biochemical attributes, antioxidant enzymes and nutrients accumulation under different levels of SS (i.e., control, $6 \mathrm{dS} \mathrm{m} \mathrm{m}^{-1}, 12 \mathrm{dS} \mathrm{m}^{-1}$ ). Salt stress diminished the root and shoot length, root and shoot biomass, chlorophyll contents, photosynthetic rate $(P n)$, stomatal conductance $(\mathrm{gs})$, relative water contents (RWC), soluble proteins (SP) and free amino acids; (FAA); and increased activities of antioxidant enzymes, electrical conductivity (EC) and accumulation of malondialdehyde (MDA), hydrogen peroxide $\left(\mathrm{H}_{2} \mathrm{O}_{2}\right), \mathrm{Na}^{+}$ and $\mathrm{Cl}^{-}$ions. GB application significantly increased root and shoot growth, leaves per plant, shoots length, chlorophyll contents, gs, $P n$ and membrane stability by reducing $\mathrm{MDA}$ and $\mathrm{H}_{2} \mathrm{O}_{2}$ accumulation. Moreover, GB also increased the SP, FAA accumulation, activities of antioxidant enzymes and $\mathrm{Na}^{+}$and $\mathrm{Cl}^{-}$exclusion by favouring $\mathrm{Ca}^{2+}$ and $\mathrm{K}^{+}$accumulation. In conclusion, the foliar-applied GB increased $P n$, gs, ant-oxidants activities, and accumulation of SP and FAA; and reduced the accretion of $\mathrm{Na}^{+}$and $\mathrm{Cl}^{-}$by favouring the $\mathrm{Ca}^{2+}$ and $\mathrm{K}^{+}$accretion which in turns improved growth under SS.

Keywords: antioxidants; growth, glycine-betaine; nutrients accumulation; photosynthesis; salt stress; soluble proteins

Abbreviation: APX: ascorbate peroxide, AsA: ascorbic acid, Ca: calcium, $\mathrm{Cl}^{l}$ : chloride, CAT: catalase, DAP: di-ammonium phosphate, EC: electrical conductivity, FAA: free amino acids, FW: fresh weight, $\mathrm{H}_{2} \mathrm{O}_{2}$ :

Received: 01 Feb 2021. Received in revised form: 24 Feb 2021. Accepted: 01 Mar 2021. Published online: 02 Mar 2021.

From Volume 49, Issue 1, 2021, Notulae Botanicae Horti Agrobotanici Cluj-Napoca journal will use article numbers in place of the traditional method of continuous pagination through the volume. The journal will continue to appear quarterly, as before, with four annual numbers. 
hydrogen peroxide, K: potassium, KI: potassium iodide, LPP: leaves per plant, MDA: malondialdehyde, mM: milli molar Na: sodium, OS: oxidative stress, Pn: photosynthetic rate, POD: peroxidase, ROS: reactive oxygen species, RL: root length, RWC: relative water contents, gs: stomatal conductance, SL: shoot length, SP: soluble protein, SS: salinity stress, TCA: trichloroacetic acid, WUE: water use efficiency.

\section{Introduction}

Salinity stress (SS) is one of the critical factors of abiotic stress that substantially diminishes crop growth, development, and production (Mbarki et al., 2018; Seleiman and Kheir, 2018; Seleiman, 2019; Seleiman et al., 2020). Globally, more than $20 \%$ cultivated lands and $33 \%$ irrigated agriculture lands are facing salinity stress problems. Additionally, it has been predicted that more than $50 \%$ of world arable lands will be salinized by the end of 2050 (Jamil et al., 2011; Shrivastava and Kumar, 2015). The effects of salt stress have been reported in most of the world's crops (Seleiman and Kheir, 2018; Al-Ashkar et al., 2020), including maize, which is the most imperative staple food of many nations. Salinity stress has a drastic effect on plant morphology and physiology due to the physiologically mediated osmotic stress. This can result imperfections in plant water relations and ionic balance that eventually leads to ionic toxicity of plant metabolic processes (Semida et al., 2016; Al-Ashkar et al., 2019; Seleiman et al., 2020). Moreover, SS can induce the overproduction of reactive oxygen species (ROS), which triggers the oxidative stress (OS) in different plant tissues, and causes chlorophyll degradation and oxidation of significant molecules including lipids, proteins and DNA (Radi, 2018).

Additionally, elevated SS can reduce the photosynthetic efficiency, plants growth and productivity and can induce the accumulation of toxic ions (Abd El-Mageed et al., 2017; Taha et al., 2021). Therefore, to mitigate the negative impacts of SS, plants have different mechanisms to protect themselves from the effects of OS by inducing the activities of various enzymatic and non-enzymatic antioxidants (Semida et al., 2014). Furthermore, plants can accumulate different solutes and have ion homeostasis mechanisms that can protect them from the negative effects of SS (Zhu, 2002). Therefore, to support the endogenous plant mechanisms, different efforts have been made to mitigate the negative impacts of SS. Among these, foliar application of osmo protectants is an important approach to ensure the crops survival and improve the production in salt-affected soils (Semida et al., 2017; Rady et al., 2018; Seleiman et al., 2020).

The variable osmolytes, including the proline, soluble sugar, amino acids and GB are endogenously produced in plants which protect them from salt- and heavy metals stresses (Hoque et al., 2007; Aamer et al., 2018; Ali et al., 2020; Seleiman et al., 2020; Seleiman et al., 2021). The accumulation of these substances also maintains the subcellular structures and diminishes the oxidative effects of ROS in high salt stress (Slama et al., 2015). GB is synthesized in plants as a result of SS; however, GB synthesis and accumulation largely depends upon the degree of SS tolerance (Sakamoto and Murata, 2000). Plants can decrease the accumulation of GB; therefore, exogenous applied GB can improve SS tolerance in plants (Kaya et al., 2013; Alasvandyari et al., 2017). GB can maintain the osmotic regulation and support the diverse transporters for the optimum functioning under SS (Gadallah, 1999).

GB can be applied to the crops as foliar spray and seed priming to mitigate the adverse effect of different stresses (Ali et al., 2020). The foliar application of GB can improve the growth and activity of antioxidant enzymes which can mitigate the adverse effects of SS (Ma et al., 2006; Alasvandyari et al., 2017). The GB

application also can improve the stomatal conductance (gs), chlorophyll contents, RWC, membrane stability and water use efficiency (WUE) which can cause an improvement in crop performance under SS conditions (Rady et al., 2018). Moreover, the GB differentiates $\mathrm{Na}^{+}$against $\mathrm{K}^{+}$under SS conditions (Mansour 1998), and improves the root cells' efficacy to accumulate more $\mathrm{Na}^{+}$in plants grown under SS conditions (Rahman et al., 2002). Additionally, GB application can improve the $\mathrm{K}^{+}$accumulation, and reduce $\mathrm{Na}^{+}$and malondialdehyde (MDA) accumulation in plant under SS conditions ( Hu et al., 2012), favouring overall plant growth. Maize is 
an imperative crop, and it is globally cultivated for food, feed and bioenergy purposes (Seleiman et al., 2013). However, the SS can have devastating impacts on maize growth and production.

The mechanisms lying behind the reduction of SS effects as a result of GB application in maize are still poorly understood. Therefore, they should be adequately elucidated. In the current investigation, we hypothesized that $\mathrm{GB}$ application would improve the salt tolerance in maize crop by improving antioxidant system activities, accumulation of $\mathrm{K}^{+}$and $\mathrm{Ca}^{2+}$, and different physio-biochemical processes. Thus, the present investigation was performed to investigate the GB's effects on maize growth, photosynthetic attributes, ROS, antioxidant activities, and ions accumulation under SS conditions.

\section{Materials and Methods}

\section{Experimental location}

The pot study was performed to evaluate foliar-applied GB's impact on maize crop performance under different SS at the Agriculture Faculty, University of Agriculture, Faisalabad, Pakistan. The upper $1-10 \mathrm{~cm}$ layer of the soil was properly collected from the field, adequately sieved and finally stored in the laboratory. The various soil, physio-chemical properties were determined using the standard methods as described by Homer and Pratt (1961). The soil was loamy with pH 7.6, EC $1.04 \mathrm{dSm}^{-1}$, organic matter $0.82 \%$, available $\mathrm{N} 0.035 \%$, available $\mathrm{P} 11 \mathrm{mg} \mathrm{kg}^{-1}$ and available $\mathrm{K} 181 \mathrm{mg} \mathrm{kg}^{-1}$.

\section{Imposition of salinity and experimental treatments}

After adding the distilled water $\left(\mathrm{dH}_{2} \mathrm{O}\right)$; the soil was well mixed and left for $2 \mathrm{~h}$ to reach the equilibrium. Moreover, the extract was attained by filtering the soil paste with filter paper and saturation $\%$ was calculated as given by the formula:

$$
\text { Saturation }(\%)=\frac{\text { Loss in soil weight on drying }}{\text { Weight of soil after drying }} \times 100
$$

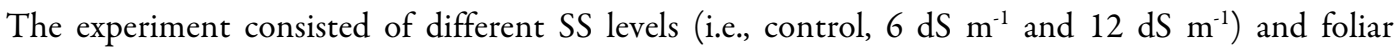
application of GB (i.e. control, $50 \mathrm{mM}$ and $100 \mathrm{mM}$ ). The various SS treatments were applied to the soil before sowing. The concentration of salts required to attain each SS level was calculated by given below formula:

$$
\text { NaCl required }\left(\frac{\mathrm{g}}{\mathrm{kg}}\right)=\frac{\text { TSS } \times 58.5 \times \text { Saturation }(\%)}{100 \times 1000}
$$

The plastic pots having a capacity of $8 \mathrm{~kg}$ with a diameter of $28 \mathrm{~cm}$ was used for the study. In total 27 pots were used for the study. The soil for each pot was taken, and salt was appropriately mixed in soil. Next, the pots were filled with the soil. Moreover, ten seeds of maize were sown in each pot. Uniform irrigation was given to each pot when water was required to avoid the drought conditions. To enhance the nutrient uptake, urea and DAP (di-ammonium phosphate) were used twice during the experiment. After 15 days, GB was applied as a foliar spray with handheld sprayer according to the different treatments, whereas water was sprayed into control pots.

\section{Growth parameters}

After 15 days of GB application, five plants from each pot were uprooted, and roots were separated from the base. The length of root and shoots was measured and averaged. Similarly, the root and shoot's fresh weight was taken and averaged. Then, roots and shoots were oven-dried to determine the dry weight. In addition, the leaves of the same plants were counted and averaged.

\section{Determination of relative water contents}

RWC was determined after 10 days of the GB foliar spray according to Mostofa and Fujita (2013). Firstly, leaf samples were weighed (FW) and then submerged in $\mathrm{H}_{2} \mathrm{O}$ in a disposable cup for 24 hours. The 
excess water from the samples was removed with a paper towel. Then, the turgid water (TW) was immediately determined. Afterwards, samples were placed in the oven for $48 \mathrm{~h}$ at $70^{\circ} \mathrm{C}$, and then dry weight was recorded. Finally, the leaf RWC was determined by the following formula:

$$
R W C(\%)=\frac{F W-D R}{T W-D R} \times 100
$$

\section{Electrical conductivity}

For electrical conductivity (EC): fresh leaf samples were taken and washed with $\mathrm{dH}_{2} \mathrm{O}$ to remove contamination. The leaves were placed in stopper vials containing $10 \mathrm{~mL} \mathrm{dH_{2 }} \mathrm{O}$ and incubated $\left(25^{\circ} \mathrm{C}\right)$ on a rotary-shaker. First, EC $\left(\mathrm{E}_{1}\right)$ of the solution was recorded after 24 hours. Then, samples were autoclaved for 20 min at $120^{\circ} \mathrm{C}$, and last $\mathrm{EC}\left(\mathrm{E}_{2}\right)$ was recorded upon equilibrium at $25^{\circ} \mathrm{C}$. The $\mathrm{EC}$ was determined using a given equation:

$$
\text { E. } C=\frac{E I}{E 2} \times 100
$$

\section{Chlorophyll and carotenoid contents}

Chlorophyll a, b and carotenoid were recorded according to Lichtenthaler (1987). The leaf samples were washed to remove the contaminations before extraction. After that, one $g$ of the leaves was taken and homogenized in a $90 \%$ acetone using the mortar and pestle. The extracts were centrifuged. The absorbance was recorded at $663,645,470 \mathrm{~nm}$ using a spectrophotometer.

\section{Malondialdehyde and $\mathrm{H}_{2} \mathrm{O}_{2}$ determination}

Malondialdehyde was recorded according to Rao and Sresty (2000). About $0.5 \mathrm{~g}$ frozen sample was homogenized in a $5 \mathrm{~mL}$ of trichloroacetic acid (TCA), and then was centrifuged for $15 \mathrm{~min}$ at 12,000 on $4{ }^{\circ} \mathrm{C}$. The mixture containing supernatant was added with $5 \mathrm{~mL}$ of thiobarbituric acid (TBA) and heated at $100^{\circ} \mathrm{C}$ for $30 \mathrm{~min}$. Then it was quickly cooled at $40{ }^{\circ} \mathrm{C}$ in ice baths. After that, the supernatant value was read at 532 and $600 \mathrm{~nm}$, and MDA contents were expressed in $\mu \mathrm{mol} / \mathrm{g} \mathrm{FW}$. Hydrogen peroxide $\left(\mathrm{H}_{2} \mathrm{O}_{2}\right)$ concentration was recorded according to Velikova et al. (2000). Plant sample $(0.5 \mathrm{~g})$ was ground in a $5 \mathrm{~mL}$ of TCA and was centrifuged. Then, it was placed into the test tube, and $1 \mathrm{M}$ potassium iodide (KI) and $100 \mu \mathrm{l}$ potassium phosphate buffer was added. It was maintained for $30 \mathrm{~min}$ at the room temperature. Then, the absorbance was measured at $390 \mathrm{~nm}$ and later was expressed as $\mu \mathrm{mol} / \mathrm{g} \mathrm{FW}$ basis.

\section{Antioxidant enzymes}

The catalase (CAT) contents were determined by the described method of Aebi (1984). The test tube contained a $100 \mu \mathrm{L}$ of $\mathrm{H}_{2} \mathrm{O}_{2}(5.9 \mathrm{Mm})$ and $1000 \mu \mathrm{L}$ buffer along with the $100 \mu \mathrm{L}$ of plant extract. The absorbance of samples was recorded at $240 \mathrm{~nm}$ using spectrophotometer. Peroxidase (POD) was determined by the procedure of Zhang (1992). The combinations of reactants containing $100 \mu \mathrm{L}$ extract enzyme +2700 $\mu \mathrm{L}$ of $50 \mathrm{mM}$ potassium buffers $+100 \mu \mathrm{L}$ guiaicol and $\mathrm{H}_{2} \mathrm{O}_{2} 100 \mu \mathrm{L}$ was used for the analysis. The plant sample $(0.5 \mathrm{~g})$ was homogenized using $5-\mathrm{mL}$ potassium phosphate buffer $(50 \mathrm{mM})$ with $7.0 \mathrm{pH}$ under ice-cold conditions and centrifuged at 15,000. The absorbance of the extract was recorded at $470 \mathrm{~nm}$ for $2 \mathrm{~min}$. For ascorbate peroxide (APX) determination, the mixture contained 100- $\mu \mathrm{L}$ enzymes extracts, $100 \mu \mathrm{L}$ ascorbate (7.5-mM), $100 \mu \mathrm{L} \mathrm{H}_{2} \mathrm{O}_{2}(300 \mathrm{mM})$, and $2.7 \mathrm{~mL}$ potassium buffer $(25 \mathrm{mM})$, 2-mM CA having $7.0 \mathrm{pH}$. The activity of APX was determined at $290 \mathrm{~nm}$ wavelength using spectrophotometer. Ascorbic acid (AsA) was determined by the described method of Mukherjee and Chouduri (1983). The plant sample (0.5 g) was standardized at $5 \mathrm{~mL}$ of $10 \%$ tri-chloroacetic acid solution. The samples were centrifuged at $8000 \mathrm{rpm}$ for 10 $\mathrm{min}$. Then, $0.5 \mathrm{~mL}$ of DTC regent was added in $2 \mathrm{~mL}$ supernatant and incubated for $3 \mathrm{~h}$ cooled. Then, $2 \mathrm{~mL}$ of sulfuric acid was added as dropwise and slightly shacked. The mixture was kept for $30 \mathrm{~min}$ at $30^{\circ} \mathrm{C}$, and the absorbance was recorded at $520 \mathrm{~nm}$ using spectrophotometer. 


\section{Determination of total soluble protein and amino acids}

Total SP was determined by the mesthos published in Bradford (1976). Samples of leaves $(0.5 \mathrm{~g})$ were ground with $5 \mathrm{~mL}$ phosphate buffer (pH 7.8) and centrifuged at $15000 \mathrm{rpm}$ for $15 \mathrm{~min}$. Then, $1 \mathrm{~mL}$ of plant extraction was transferred in test tubes with $3 \mathrm{~mL}$ Bradford reagent, and were left for $15 \mathrm{~min}$ at room temperature. The concentration of the total SP was recoded at $595 \mathrm{~nm}$ using spectrophotometer. Total free amino acid (FAA) was analyzed using method of Hamilton and Van Slyke (1943). Then, $1 \mathrm{~mL}$ extract was taken and placed into the test tubes with $1 \mathrm{~mL}$ of ninhydrin and pyridine. The samples were placed into the water bath for $30 \mathrm{~min}$ at $90^{\circ} \mathrm{C}$. Afterwards, their volume was maintained to $25 \mathrm{~mL}$ by adding $\mathrm{dH}_{2} \mathrm{O}$, and the total FAA concentration was recoded $570 \mathrm{~nm}$ using spectrophotometer.

\section{Determination of ion accumulation}

The plants' samples (roots and leaves) were washed with $\mathrm{dH}_{2} \mathrm{O}$ to remove any of the contamination. Then, plant samples were oven-dried $\left(65^{\circ} \mathrm{C}\right)$ and milled to get the powder. The powdered samples $(0.5 \mathrm{~g})$ were digested with $1: 2$ of $\mathrm{HCL}$ and $\mathrm{HNO}_{3}$ for 10 min at $180^{\circ} \mathrm{C}$, filtered and diluted with a distilled water. The $\mathrm{Na}^{+}$, $\mathrm{Cl}, \mathrm{K}^{+}$and $\mathrm{Ca}^{2+}$ concentrations were analyzed using flame photometer (Jones and Case, 1990).

\section{Experimental design and data analysis}

The study was performed in a completely randomized design with the factorial arrangement, and each treatment was replicated three times. The data were statistical analyzed using two-way ANNOVA and least significant difference test (LSD) was employed to determine difference between different treatments at $P \leq$ 0.05 (Steel et al., 1997). The PCA and heat map were made using R-studio software.

\section{Results}

\section{Growth and biomass accumulation}

The different SS levels resulted in a significant reduction in growth attributes than the control treatment (Table 1). The reduction in growth traits was noted under all SS levels, but the maximum reduction was recorded with the highest SS level (i.e. $12 \mathrm{dS} \mathrm{m}^{-1}$ ) (Table 1). However, the foliar-applied GB appreciably increased the growth traits of plants grown under all SS levels and control treatment. The maximum root length $(\mathrm{RL} ; 13 \mathrm{~cm})$ and shoot length $(\mathrm{SL} ; 57.7 \mathrm{~cm})$ was noticed in plants grown under the control treatment with the foliar applied GB of $100 \mathrm{mM}$, and the lowest RL $(8.6 \mathrm{~cm})$ and SL $(44.4 \mathrm{~cm})$ were noticed with the highest SS level without GB application (Table 1). Similarly, the root and shoot biomass were decreased with increasing SS levels. However, the highest foliar-applied GB (i.e. $100 \mathrm{mM}$ ) markedly enhanced root and shoot fresh and dry biomass of plants grown under all SS levels (Table 1). The maximum LPP (6) was recorded from plants grown in control with the application of $100 \mathrm{mM} \mathrm{GB}$, and lowest LPP (3) was recorded from plants grown with the highest SS level (i.e. $12 \mathrm{dS} \mathrm{m}^{-1}$ ) without foliar-applied GB (Table 1).

\section{Photosynthetic attributes}

Salt stress significantly decreased the chlorophyll and carotenoid contents (Figure 1). Chlorophyll a

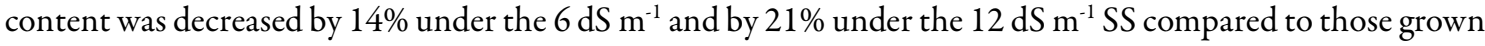
in control treatment. Moreover, foliar application of GB with $50 \mathrm{mM}$ and $100 \mathrm{mM}$ increased the chlorophyll a content by approximately $9 \%$ and $16 \%$ under $12 \mathrm{dS} \mathrm{m}^{-1} \mathrm{SS}$, respectively (Figure 1). The similar response was observed for chlorophyll b. For example, the reductions in chlorophyll b contents were $16 \%$ and $32 \%$ in plants

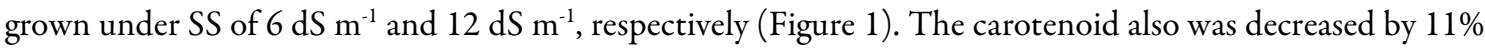
and $19 \%$ at $6 \mathrm{dS} \mathrm{m}^{-1}$ and $12 \mathrm{dS} \mathrm{m}^{-1} \mathrm{SS}$ level, respectively. Moreover, GB application at $100 \mathrm{mM}$ considerably increased the carotenoid contents compared to the application of $50 \mathrm{mM} \mathrm{GB}$ and control treatment (Figure 1). The $S S$ significantly reduced gs, $P n$ and transpiration rates. However, GB application remarkably increased 
the gs, $P n$ and transpiration rates in plants grown with different $S S$ treatments (Figure 1). The gs and $P_{n}$ was decreased by $31 \%$ and $41 \%$ at $12 \mathrm{dS} \mathrm{m}^{-1}$ SS level, respectively. However, GB application of $100 \mathrm{mM}$ increased the gs and $P_{n}$ by $21 \%$ and $22 \%$ under $12 \mathrm{dS} \mathrm{m}^{-1}$, respectively (Figure 1 ). The transpiration rate was decreased by $21 \%$ and $50 \%$ in $6 \mathrm{dS} \mathrm{m} \mathrm{m}^{-1}$ and $12 \mathrm{dS} \mathrm{m}$, whereas the GB application with $100 \mathrm{mM}$ increased the transpiration rate by $16 \%$ and $14 \%$ in both aforementioned SS levels, respectively (Figure 1).

Table 1. Effect of GB application on growth attributes of maize grown under salt stress

\begin{tabular}{|c|c|c|c|c|c|c|c|c|}
\hline \multicolumn{2}{|c|}{ Treatments } & RL $(\mathrm{cm})$ & SL $(\mathrm{cm})$ & RFW $(\mathrm{g})$ & SFW $(\mathrm{g})$ & RDW $(\mathrm{g})$ & SDW $(\mathrm{g})$ & LPP \\
\hline \multirow{3}{*}{ Control } & Control & $10.33 \pm 1.31 \mathrm{~cd}$ & $51.66 \pm 3.86 \mathrm{bc}$ & $3.72 \pm 0.09 \mathrm{a}$ & $11.36 \pm 0.39 \mathrm{~b}$ & $1.66 \pm 0.02$ & $2.31 \pm 0.05 \mathrm{~cd}$ & $4.00 \pm 0.81 \mathrm{bc}$ \\
\cline { 2 - 9 } & $\mathbf{5 0 \mathrm { mM }}$ & $12.00 \pm 0.21 \mathrm{ab}$ & $53.66 \pm 1.25 \mathrm{~b}$ & $3.75 \pm 0.04 \mathrm{ab}$ & $11.62 \pm 0.47 \mathrm{ab}$ & $1.71 \pm 0.01$ & $2.40 \pm 0.04 \mathrm{bc}$ & $5.00 \pm 0.81 \mathrm{ab}$ \\
\cline { 2 - 9 } & $100 \mathrm{mM}$ & $13.00 \pm 0.81 \mathrm{a}$ & $57.66 \pm 2.62 \mathrm{a}$ & $3.82 \pm 0.08 \mathrm{a}$ & $12.94 \pm 0.13 \mathrm{a}$ & $1.80 \pm 0.01$ & $2.53 \pm 0.07 \mathrm{a}$ & $6.00 \pm 0.81 \mathrm{a}$ \\
\hline \multirow{3}{*}{$6 \mathrm{dSm}^{-1}$} & Control & $10.46 \pm 0.38 \mathrm{~cd}$ & $47.00 \pm 1.63 \mathrm{de}$ & $3.35 \pm 0.01 \mathrm{e}$ & $8.81 \pm 0.79 \mathrm{~cd}$ & $1.46 \pm 0.02$ & $2.22 \pm 0.02 \mathrm{def}$ & $3.00 \pm 0.81 \mathrm{~cd}$ \\
\cline { 2 - 9 } & $50 \mathrm{mM}$ & $11.36 \pm 0.32 \mathrm{bc}$ & $49.66 \pm 1.25 \mathrm{~cd}$ & $3.44 \pm 0.05 \mathrm{~d}$ & $11.45 \pm 1.15 \mathrm{ab}$ & $1.55 \pm 0.03$ & $2.34 \pm 0.05 \mathrm{bcd}$ & $4.00 \pm 0.81 \mathrm{bc}$ \\
\cline { 2 - 9 } & $100 \mathrm{mM}$ & $11.53 \pm 0.16 \mathrm{bc}$ & $49.00 \pm 1.63 \mathrm{~cd}$ & $3.63 \pm 0.04 \mathrm{c}$ & $11.58 \pm 1.21 \mathrm{ab}$ & $1.63 \pm 0.02$ & $2.44 \pm 0.04 \mathrm{ab}$ & $5.00 \pm 0.81 \mathrm{ab}$ \\
\hline \multirow{3}{*}{$12 \mathrm{dSm}^{-1}$} & Control & $8.63 \pm 0.26 \mathrm{e}$ & $44.44 \pm 1.70 \mathrm{e}$ & $3.04 \pm 0.02 \mathrm{~g}$ & $8.67 \pm 0.94 \mathrm{~d}$ & $1.35 \pm 0.01$ & $2.10 \pm 0.08 \mathrm{f}$ & $2.00 \pm 0.81 \mathrm{~d}$ \\
\cline { 2 - 9 } & $50 \mathrm{Mm}$ & $9.66 \pm 0.47 \mathrm{de}$ & $48.66 \pm 2.05 \mathrm{~cd}$ & $3.18 \pm 0.05 \mathrm{f}$ & $8.37 \pm 0.46 \mathrm{~d}$ & $1.44 \pm 0.02$ & $2.15 \pm 0.03 \mathrm{ef}$ & $3.00 \pm 0.81 \mathrm{~cd}$ \\
\cline { 2 - 9 } & $100 \mathrm{Mm}$ & $10.66 \pm 0.33 \mathrm{~cd}$ & $44.33 \pm 2.05 \mathrm{e}$ & $3.36 \pm 0.00 \mathrm{e}$ & $10.25 \pm 0.30 \mathrm{bc}$ & $1.56 \pm 0.01$ & $2.25 \pm 0.10 \mathrm{de}$ & $4.00 \pm 0.81 \mathrm{bc}$ \\
\hline
\end{tabular}

The values shown in the table contain the mean value of three replications \pm S.E and different values show significant differences $(\mathrm{P} \leq 0.05)$ according to LSD test. RL: root length, SL: shoot length, RFW: root fresh weight, SFW: shoot fresh weight, RDW: root dry weight, SDW: shoot dry weight, LPP: Leaves per plant
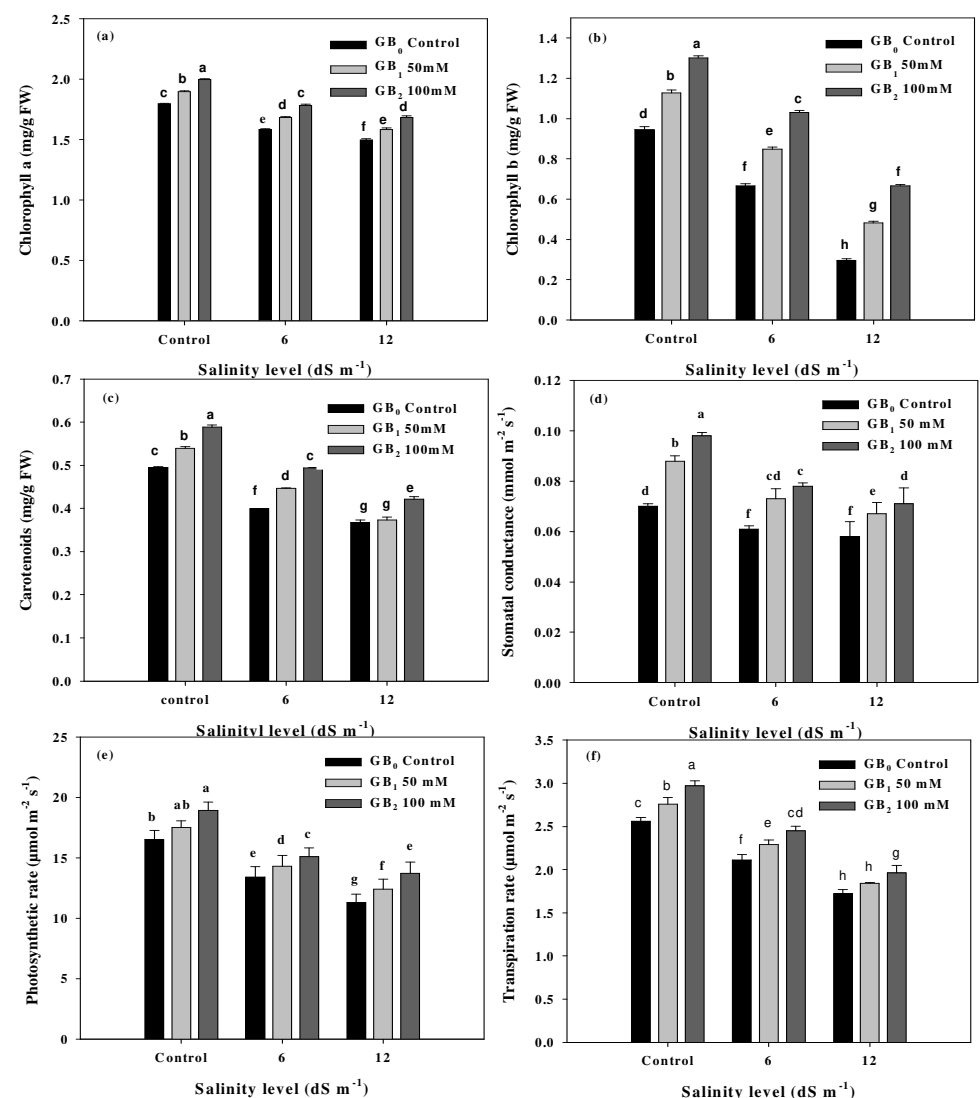

Figure 1. Effect of GB on (a) chlorophyll a, (b) chlorophyll b, (c) carotenoid, (d) stomatal conductance, (e) photosynthetic rate and (f) transpiration rate under salinity stress.

Error bars show the mean value of three replications \pm S.E and different values shows significant differences $(\mathrm{P} \leq 0.05)$ according to LSD test. 


\section{Relative water content and electrical conductivity}

RWC was reduced by $31 \%$ and $36 \%$ at $6 \mathrm{dS} \mathrm{m}^{-1}$ to $12 \mathrm{dS} \mathrm{m}^{-1}$, respectively. The exogenously applied GB (i.e. $50 \mathrm{mM}$ and $100 \mathrm{mM}$ ) markedly increased the RWC; however, the maximum increase in RWC was reported by $100 \mathrm{mM} \mathrm{GB}$ application that increased the RWC by $29 \%$ at $12 \mathrm{dS} \mathrm{m}^{-1}$ (Figure 2). EC of maize plants substantially increased with the increment in salt stress. An increase of $29 \%$ and $37 \%$ in EC was noticed under $6 \mathrm{dS} \mathrm{m}^{-1}$ and $12 \mathrm{dS} \mathrm{m}^{-1}$. Additionally, the exogenous application of GB at $50 \mathrm{mM}$ and $100 \mathrm{mM}$ significantly decreased the EC by $12 \%$ and $22 \%$ under $12 \mathrm{dSm}^{-1} \mathrm{SS}$, respectively (Figure 2).
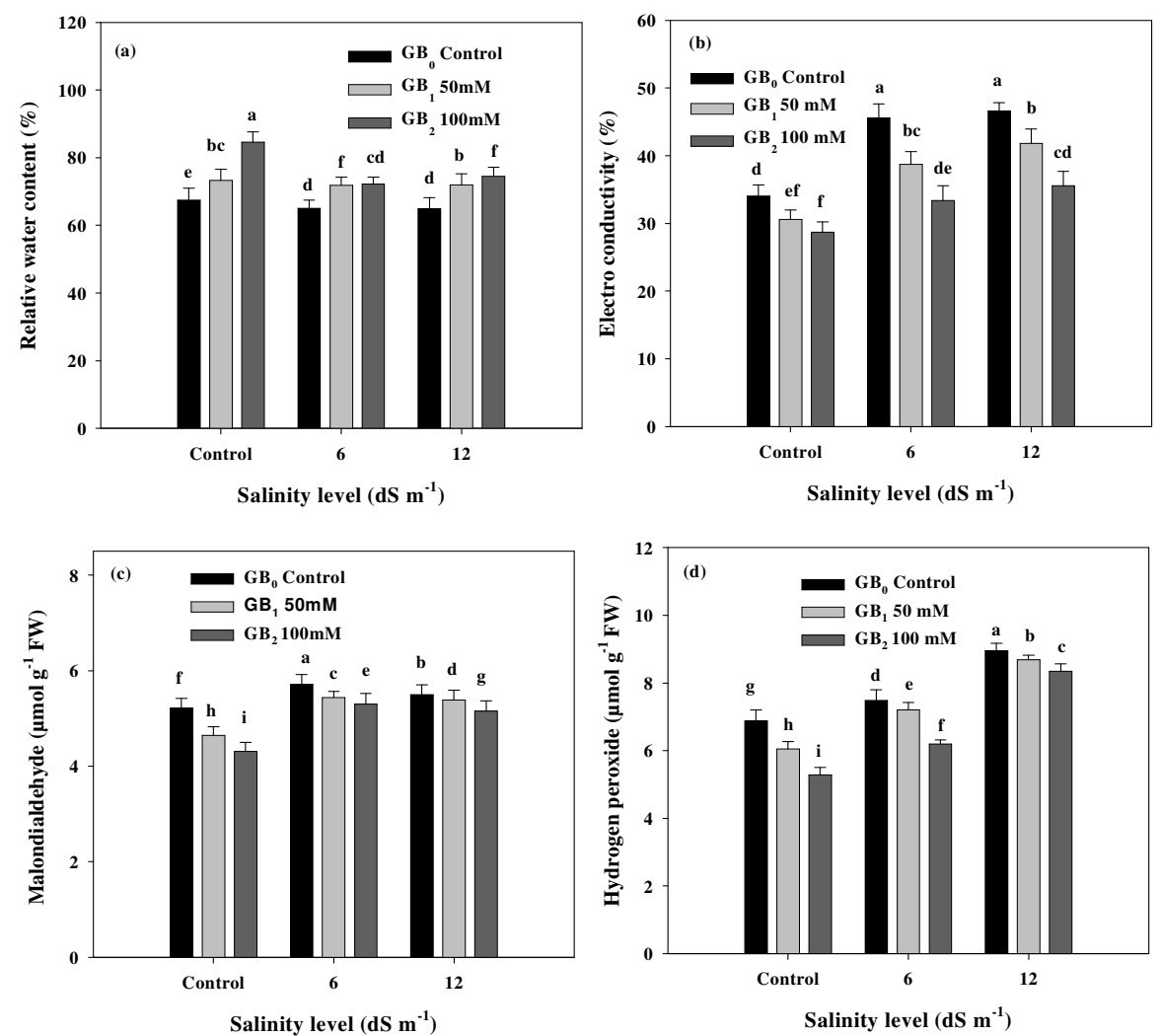

Figure 2. Effect of GB on (a) RWC, (b) EL, (c) MDA and (d) $\mathrm{H}_{2} \mathrm{O}_{2}$ under salinity stress

Error bars show the mean value of three replications \pm S.E and different values shows significant differences $(\mathrm{P} \leq 0.05)$ according to LSD test.

\section{$M D A$ and $\mathrm{H}_{2} \mathrm{O}_{2}$ contents}

MDA content was increased by $11 \%$ and $15 \%$, while $\mathrm{H}_{2} \mathrm{O}_{2}$ was increased by $21 \%$ and $38 \%$ in plants grown with $6 \mathrm{dS} \mathrm{m}^{-1}$ and $12 \mathrm{dS} \mathrm{m}^{-1}$, respectively. However, the foliar applied GB reduced the MDA and $\mathrm{H}_{2} \mathrm{O}$ content (Figure 2). A reduction of $7 \%$ and $11 \%$ in MDA content, and a reduction of $6 \%$ and $9 \%$ in $\mathrm{H}_{2} \mathrm{O}_{2}$ were observed at $50 \mathrm{mM}$ and $100 \mathrm{mM} \mathrm{GB}$ at $12 \mathrm{dS} \mathrm{m}^{-1}$, respectively (Figure 2).

\section{Antioxidant enzymes}

APX, POD and CAT activities in maize plants were significantly affected by SS (Figure 3). The POD and CAT activities were enhanced in plants grown under all SS levels, whereas both rates of $50 \mathrm{mM}$ and 100 mM GB substantially increased the POD and CAT activities (Figure 3). However, foliar-applied GB (i.e. 100 $\mathrm{mM}$ ) remained at the top, and significantly increased the POD and CAT activities by $19 \%$ and $17 \%$, respectively (Figure 6). The APX and ascorbic acid contents were increased in plants grown with $6 \mathrm{dS} \mathrm{m}^{-1}$ and $12 \mathrm{dS} \mathrm{m}^{-1} \mathrm{SS}$. Moreover, GB application with $50 \mathrm{mM}$ and $100 \mathrm{mM}$ significantly increased the APX and ascorbic 
acid in plants grown with both levels of SS (Figure 3). Similarly, AS content was increased in SS. Moreover, GB increased the AsA content, which can be a clear indication for the increment of antioxidant activities due to GB application.
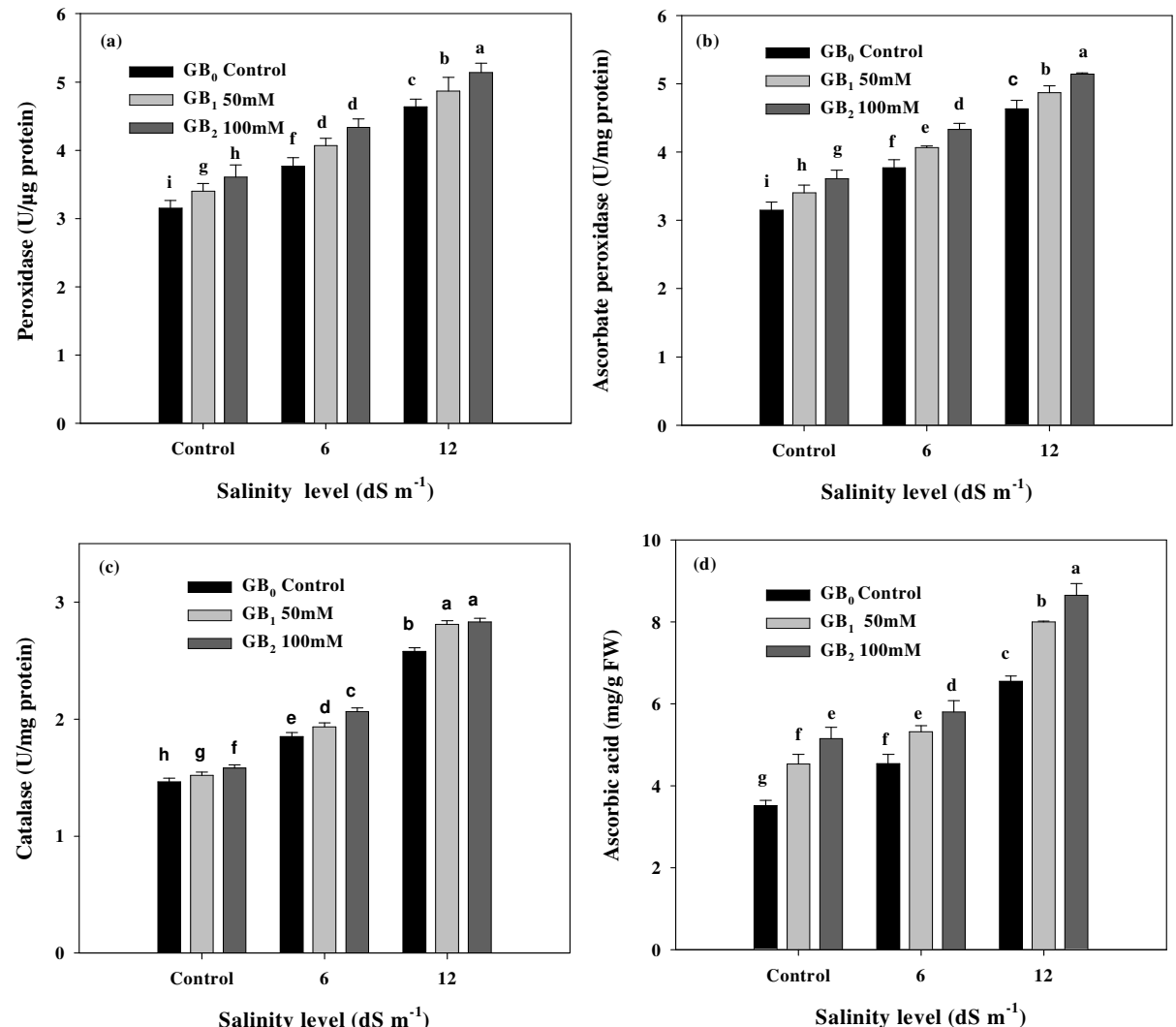

Figure 3. Effect of GB on the activity of (a) POD, (b) APX, (c) SOD and (d) ascorbic acid under salinity stress

Error bars show the mean value of three replications \pm S.E and different values shows significant differences $(P \leq 0.05)$ according to LSD test.

\section{Soluble proteins and amino acids}

Total SP and FAA in maize plants were significantly influenced by SS (Figure 4). The total SP was decreased by $13 \%$ and $25 \%$ under $6 \mathrm{dS} \mathrm{m}^{-1}$ and $12 \mathrm{dS} \mathrm{m}^{-1}$ stress condition, whereas FFA showed a reduction of $13 \%$ and $23 \%$ under the same SS (Figure 4). Both GB levels at 50- and 100-mM applications increased total SP by $11 \%$ and $16 \%$ under SS $12 \mathrm{dS} \mathrm{m}^{-1}$ compared to control, respectively (Figure 4). The similar response was observed for FAA, and was increased by $9 \%$ and $17 \%$ with $50 \mathrm{mM}$ and $100 \mathrm{mM} \mathrm{GB}$ application, respectively. Anthocyanin was decreased by $13 \%$ at $6 \mathrm{dS} \mathrm{m}^{-1}$ and by $21 \%$ at $12 \mathrm{dS} \mathrm{m}^{-1} \mathrm{SS}$ (Figure 4 ).

\section{Ion accumulation}

The variable SS levels and GB application $(50 \mathrm{mM}$ and $100 \mathrm{mM})$ had significant differences for the root and leaf $\mathrm{Na}^{+}, \mathrm{Cl}, \mathrm{K}^{+}$and $\mathrm{Ca}^{2+}$ contents (Figure 5 and 6). $\mathrm{Na}^{+}$and $\mathrm{Cl}^{-}$in roots and leaves was significantly increased with increasing SS levels (Figure 5), whereas the $\mathrm{K}^{+}$and $\mathrm{Ca}^{2+}$ contents were decreased with increase in SS levels (Figure 5). Moreover, both levels of foliar-applied GB significantly decreased the $\mathrm{Na}^{+}$and $\mathrm{Cl}$, accumulation, however, the maximum reduction in $\mathrm{Na}^{+}$and $\mathrm{Cl}^{-}$, accumulation was recorded with $100 \mathrm{mM} \mathrm{GB}$ under both SS levels (Figure 5). Additionally, both GB application levels increased the accumulation of $\mathrm{K}^{+}$and $\mathrm{Ca}^{2+}$ in maize roots and shoots (Figure 6). However, $100 \mathrm{mM} \mathrm{GB}$ remarkably increased the $\mathrm{K}^{+}$accumulation 
by $13 \%$ and $39 \%$, and increased the $\mathrm{Ca}^{2+}$ accumulation by $55 \%$ and $37 \%$ in roots and leaves under $12 \mathrm{dS} \mathrm{m}^{-1} \mathrm{SS}$, respectively (Figure 6).
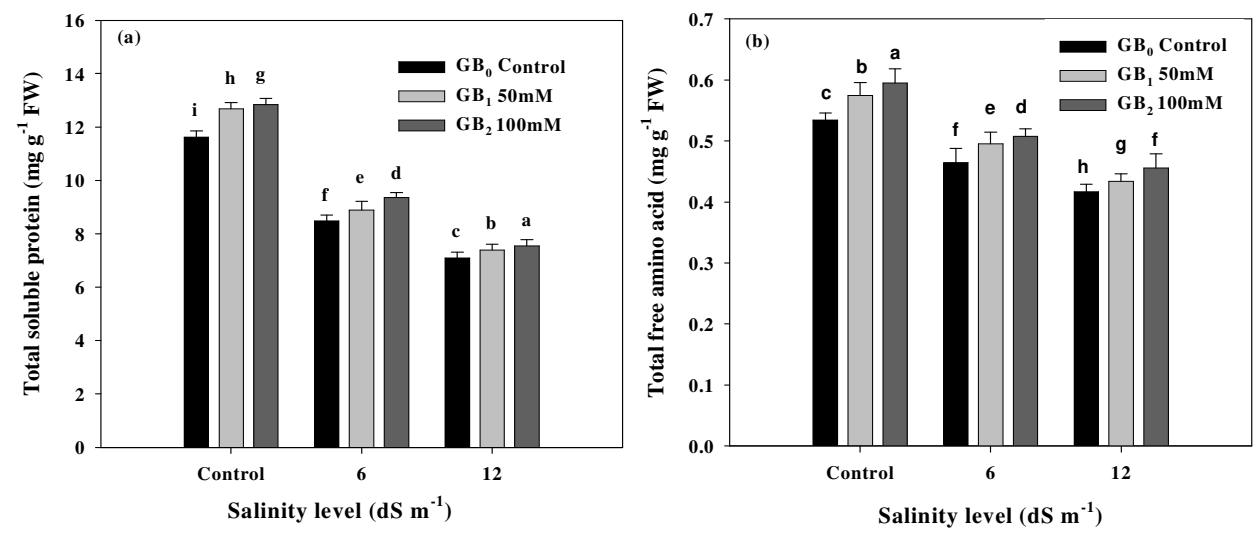

Figure 4. Effect of GB on (a) soluble proteins and (b) free amino acids under salinity stress

Error bars shows the mean value of three replications \pm S.E and different values shows significant differences $(\mathrm{P} \leq 0.05)$ according to LSD test.
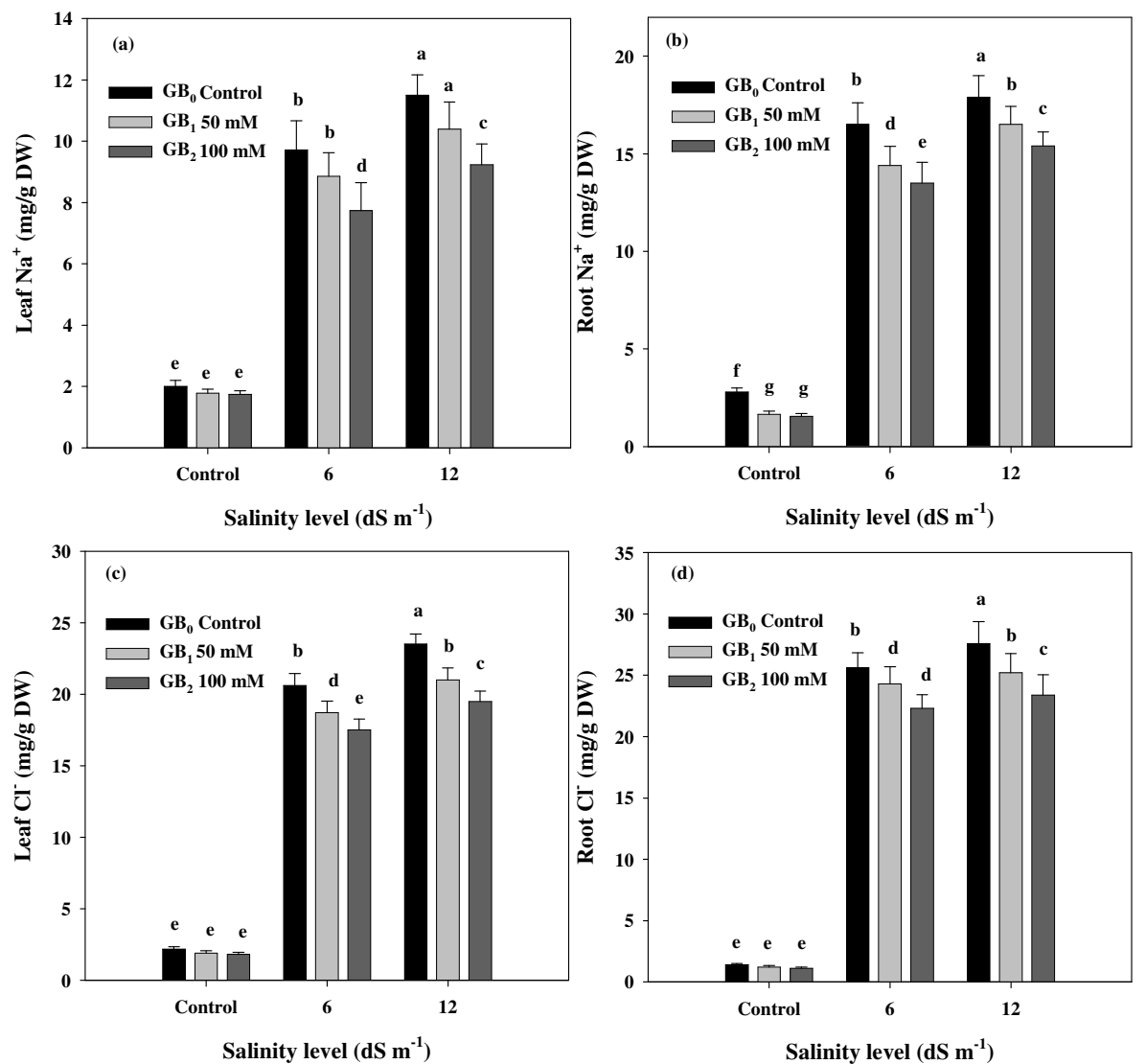

Figure 5. Effect of $\mathrm{GB}$ on (a) leaf $\mathrm{Na}^{+}$, (b) root $\mathrm{Na}^{+}$, (c) leaf $\mathrm{Cl}^{-}$and root $\mathrm{Cl}^{-}$under salinity stress Error bars show the mean value of three replications \pm S.E and different values shows significant differences $(P \leq 0.05)$ according to LSD test. 


\section{Principal component analysis (PCA)}

The data set were subjected to PCA for checking the relationship among the treatments and different parameters. The two components (i.e. PC1 and PC2) showed a 95\% total variance in which PC1 had a share of $85.1 \%$, and PC2 had a share of $8.9 \%$ (Figure 7). The SS at $12 \mathrm{dS} \mathrm{m}^{-1}$ had more destructive effects; likewise, GB applied at $100 \mathrm{mM}$ significantly ameliorated the effects of SS compared to the control and $50 \mathrm{mM} \mathrm{GB}$ treatments. The first group of variables of PC1 indicated the positive correction, whilst the second group of variables with PC2 indicated the negative relationship.
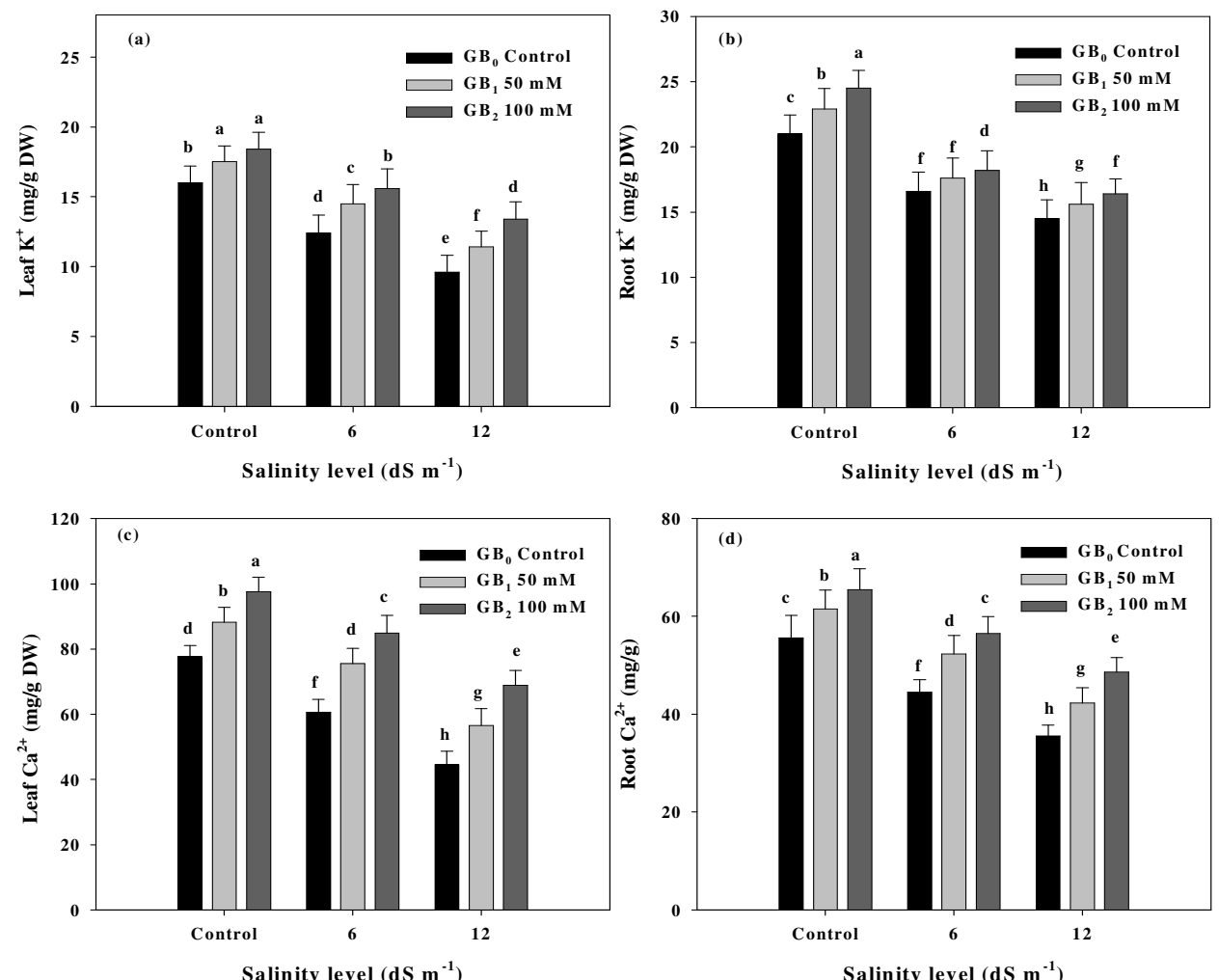

Figure 6. Effect of GB on (a) leaf $\mathrm{K}^{+}$, (b) root $\mathrm{K}^{+}$, (c) leaf $\mathrm{Ca}^{2+}$ and root $\mathrm{Ca}^{2+}$ under salinity stress Error bars show the mean value of three replications \pm S.E and different values shows significant differences $(\mathrm{P} \leq 0.05)$ according to LSD test.

\section{Discussion}

Salinity stress is one of the significant problems that can affect field crops in all climates worldwide, which has the negative impacts on the crop productivity (Seleiman et al., 2018; Seleiman et al., 2020). In the present study, different levels of SS negatively affected the growth and biomass production of maize (Table 1). SS adversely affect the water absorption by the roots which can cause drought/osmotic stress due to the ion toxicity. The nutritional imbalances including the reduction in $\mathrm{K}^{+}$absorption is considered as an imperative osmo-protectant for plants to face the abiotic stress (Taamalli et al., 2004; Taha et al., 2020). The salinity stress induced the reductions in the water and nutrients absorption diminish assimilates production, which resulted in a significant reduction in the root and shoot growth and biomass accumulation (Table 1). 

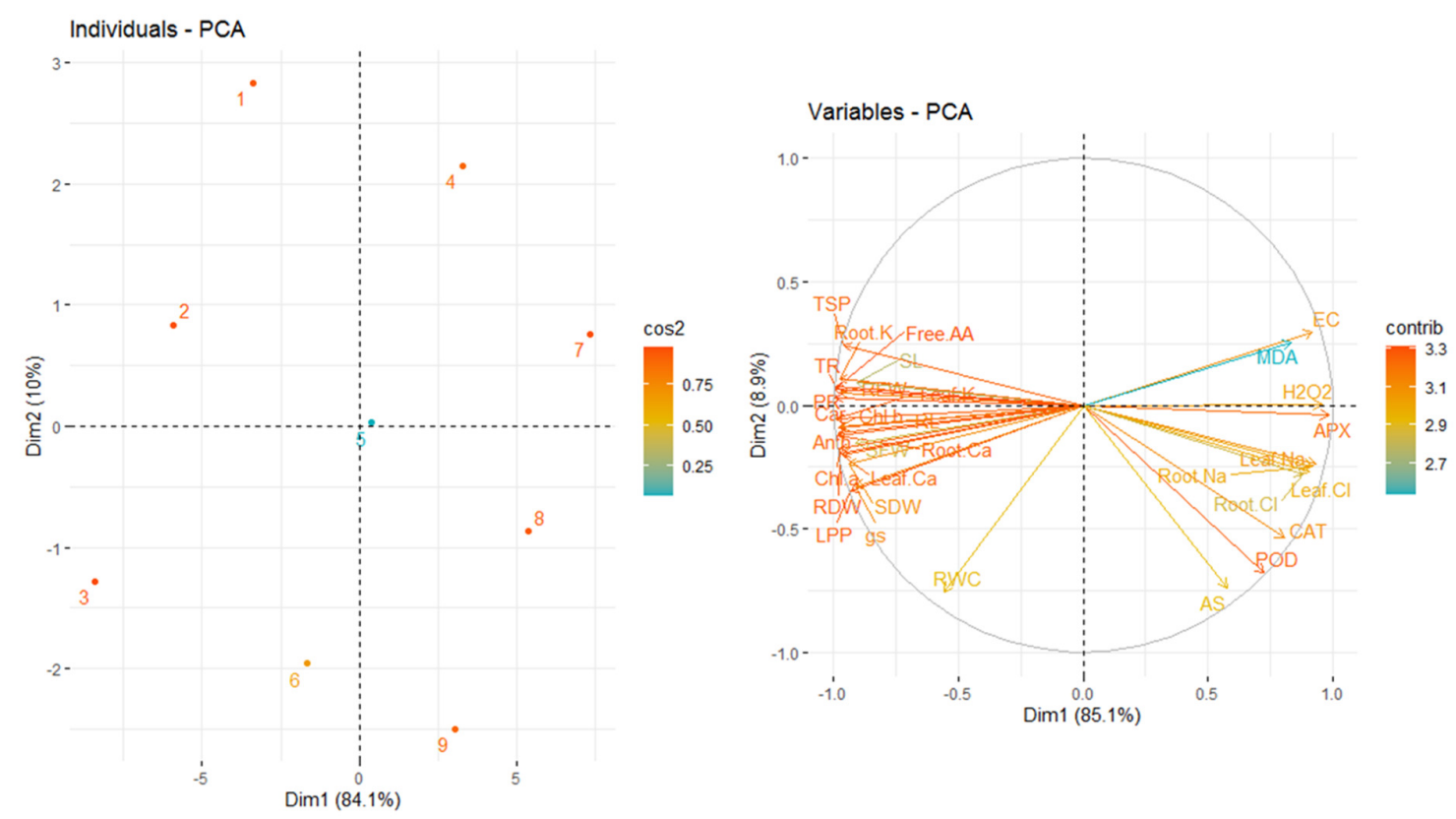

Figure 7. Scores (left) and loading plots (right) of principal component analysis (PCA) on diverse studied traits of maize

The separation of scores plots (1-9) representing the treatments. RWC: relative water content, MDA: malondialdehyde, SDW: shoot dry weight, RDW: root dry weight, gs: stomatal conductance, Car: carotenoids, FAA: free amino acids, RFW: root fresh weight, TR: transpiration rate, SL: shoot length, Anth: Anthocyanin, TSP: total soluble proteins, LPP: leaves per plant, SFW: shoot fresh weight, RL: root length, PR: photosynthetic rate, EC: electrical conductivity, APX: Ascorbate peroxidase, $\mathrm{H}_{2} \mathrm{O}_{2}$ : hydrogen peroxide, AS ascorbic acid, POD: peroxidase, CAT: catalase

Moreover, the foliar GB application appreciable improved the seedling growth and biomass production under SS conditions (Table 1). The present increase in growth as well as biomass accumulation could be due to the ameliorating effects of GB on the process of photosynthesis under SS (Figure 1). Consequently, this can result in an increment for producing more assimilates and their translocation into growing plant parts that can favore the growth and biomass accumulation (Caparrós et al., 2020). LPP was significantly affected by both SS and GB levels. The SS reduced the leaves due to the inhabited assimilates production, whilst foliar-applied GB improved the production, nutrients and water absorption (Yildirim et al., 2015; Cirillo et al., 2016; Caparrós et al., 2020), which contributed towards the production of more leaves (Table 1).

The lowest RWC in plants indicates the loss of turgor caused by the restricted availability of water which is necessary for the cell enlargement. GB application ameliorated the decrease in RWC caused by SS (Figure 2). The GB application prevents the salinity induced reduction in $\mathrm{K}^{+}$(Meloni and Martinez, 2009). Therefore, this can indirectly mediate the water retentions in plant tissues (Hu et al., 2012). The improvement in plant water relation as a result of GB applications can led to a better growth (Nawaz and Ashraf, 2007) as also noticed in the current study (Table 1). SS significantly increased the EC, accumulation of MDA and $\mathrm{H}_{2} \mathrm{O}_{2}$, (Figure 2), which are considered essential systems of SS induce damages (Moustakas et al., 2011). SS considerably changed the membrane integrity, which can be escorted by the increase in the electrolyte leakage (EL) from the plant cells (Ahmed et al., 2019). In the present study, SS significantly decreased the membrane stability accompanied by increases in $\mathrm{EC}$ and accumulation of MDA and $\mathrm{H}_{2} \mathrm{O}_{2}$ contents (Figure 2).

Nonetheless, the GB application reduced SS's damaging effects and improved membrane stability as indicated by a reduction in EC and accumulation of MDA and $\mathrm{H}_{2} \mathrm{O}_{2}$ (Figure 2). SS can cause undesirable changes in the photosynthetic efficiency and synthesis of photosynthetic pigments (Maxwell and Johnson, 2000), as also reported in the current study (Figure 1). Nonetheless, foliar feeding of GB appreciably increased 
the chlorophyll and carotenoid contents in maize seedling grown in SS conditions (Figure 1). The increment in the photosynthetic pigments by GB application might be due maintenance of endogenous water availability. Additionally, GB can protect the photo-synthetic machinery under SS by stabilizing the proteins activity under SS (Hoque et al., 2007). Such increase in the chlorophyll and carotenoid contents are in agreement with different authors who reported a significant increase in the photo-synthetic pigments with GB application on plants grown under SS (Sakr et al., 2012). SS significantly decreased the gs, $P n$ and transpiration rates (Figure 1), whilst, foliar-applied GB improved the gs, $P_{n}$ and transpiration in both control and SS conditions (Figure 1). The higher RWC and improved gs (Figure 2) by GB application was responsible for the better $P n$ and mitigation of deleterious impacts of SS (Blum, 2017; Ahmed et al., 2019). The exogenously applied GB increased the proportions of water bound in the cell owing to its hydrophilic feature, which in turns improve the turgor pressure in guard cells and thus resulting in increase in gs (Blum, 2017). Moreover, GB application in this study increased the chlorophyll contents (Figure 1), which gives an indication that GB application can delay the senescence and increases the $P n$ in plants grown under stress conditions (Mahmood et al., 2009; Abbas et al., 2010). The increase in the accumulation of FAA in plants grown under SS is considerably a significant to improve the salt tolerance in cereals (Livia et al., 2002). In this investigation, the SS reduced the accumulation of FFA; conversely the foliar applied GB $(50 \mathrm{mM}$ and $100 \mathrm{mM})$ appreciably improved the accumulation of FFA (Figure 3). The increase in the accumulation of FFA in plants can serve as an imperative compatible cytoplasmic solute for maintaining the osmotic balances under SS, which in turns can improve the growth (Table 1) and photosynthetic efficiency (Ranganayakulu et al., 2013).

The concentration of total SP substantially decreased with increasing the SS (Figure 3). Moreover, the foliar applied GB at $100 \mathrm{mM}$ significantly increased the total SP under SS. Likewise; Habib et al. (2012) noticed a significant increase in SP with a foliar spray of GB under SS. The SP can improve the cell turgor, stomatal conductance, $\mathrm{CO}_{2}$ intake, and water uptake, resulting in a significant improvement in plants performance under SS (Habib et al., 2012).

The salt stress increased ROS production (Lee et al., 2001), which can cause the oxidative damages to lipids, proteins, and DNA (Apel and Hirt, 2004). The plants protect themselves from the damaging effects of SS by activating antioxidant defense system (Mittler, 2002). The exogenous GB has the protect effects on the activities of antioxidant system under SS (Hoque et al., 2007). Foliar applied GB appreciably increased the activities of POD, CAT, APX and AsA under the SS (Figure 4). The foliar-applied GB alleviated the adverse impacts of SS by scavenging the ROS and protecting the antioxidant enzymes (Hoque et al., 2007). Similarly, the increase in activity of CAT under SS due to GB application has been also reported in rice (Demiral and Turkan 2004). Additionally, GB also increased the APX activity in plants grown in SS which indicate its ROS scavenging role (Hasanuzzaman et al., 2014) and thus resulted in better growth under SS (Table 1).

The salt tolerance in plants is linked with an increase in the $\mathrm{Na}^{+}$exclusion and $\mathrm{K}^{+}$accumulation and maintenance of optimum $\mathrm{K}^{+} / \mathrm{Na}^{+}$ratio in plants (Raza et al., 2007). The $\mathrm{K}^{+} / \mathrm{Na}^{+}$and $\mathrm{Ca}^{2+} / \mathrm{Na}^{+}$ratio can be a valid criterion to assess the SS in diverse crops (Ashraf, 2004). Therefore, $\mathrm{K}^{+}$and $\mathrm{Ca}^{2+}$ maintenance and acquisitions are imperative contributors to SS tolerance. In the present investigation, $\mathrm{Na}^{+}$accretion in roots and leaves of maize significantly increased whilst, accumulation of $\mathrm{K}^{+}$and $\mathrm{Ca}^{2+}$ considerably decreased (Figure 6). Moreover, foliar-applied GB reduced the accumulation of $\mathrm{Na}^{+}$an increase in $\mathrm{K}^{+}$and $\mathrm{Ca}^{2+}$ (Figure 5 and 6). Therefore, the improvement in the maize growth under SS with GB applied could be due to discrimination of $\mathrm{Na}^{+}$against $\mathrm{K}^{+}$and $\mathrm{Ca}^{2+}$.

The GB maintained membrane integrity under different abiotic stresses (Sakamoto and Murata, 2002). Moreover, GB also protects the diverse transporters to work typic generally under SS (Mansour, 1998). Therefore, it can be advocated that $\mathrm{GB}$ has simple protective effects in discriminating $\mathrm{Na}^{+}$against $\mathrm{K}^{+}$and $\mathrm{Ca}^{2+}$ under SS. Additionally, GB also increased the vacuole's efficiency in plant roots to accumulate more $\mathrm{Na}^{+}$ (Rahman et al., 2002). These vacuoles stored the $\mathrm{Na}^{+}$in roots and decreased the transportation of $\mathrm{Na}^{+}$to shoots and leaves. It is quite evidence in this study, $\mathrm{Na}^{+}$was less partitioned too leaves due to GB application under SS (Figure 5). 
Moreover, the $\mathrm{Ca}^{2+}$ accumulation also increased the roots due to $\mathrm{GB}$ application and the better accumulation of $\mathrm{Ca}^{2+}$ maintained the membrane integrity and enzymatic activities under SS (Munns and Tester, 2008) which reduced the EL and MDA and therefore, improved the RWC (Figure 1) and growth of maize (Table 1). The foliar-applied GB also increased the $\mathrm{K}^{+}$accumulation (Figure 6), which contributes to favouring the osmotic adjustment favouring the overall plant growth under SS (Munns and Tester, 2008). Additionally, SS also reduced the $\mathrm{Na}^{+}$accumulation (Figure 6) and maintained higher $\mathrm{K}^{+} / \mathrm{Na}^{+}$which appreciably improved the growth and slat tolerance.

\section{Conclusions}

The salt stress adversely affected the maize growth, and biomass production and these effects were appreciably reversed by the foliar-applied GB. This amelioration was a due to increase in photosynthetic pigment, gs, $P n$, membrane stability, activities of antioxidant enzymes, accumulation of free amino acids and proteins, and decrease in the accumulation of MDA and $\mathrm{H}_{2} \mathrm{O}_{2}$. For example, MDA content was increased by $11 \%$ and $15 \%$, while $\mathrm{H}_{2} \mathrm{O}_{2}$ was increased by $21 \%$ and $38 \%$ in plants grown with $6 \mathrm{dS} \mathrm{m}^{-1}$ and $12 \mathrm{dS} \mathrm{m}^{-1}$, respectively. However, a reduction of $7 \%$ and $11 \%$ in MDA content, and a reduction of $6 \%$ and $9 \%$ in $\mathrm{H}_{2} \mathrm{O}_{2}$ were observed at $50 \mathrm{mM}$ and $100 \mathrm{mM} \mathrm{GB}$ at $12 \mathrm{dS} \mathrm{m}^{-1}$, respectively. Additionally, GB reduced the ionic toxicity due to the reduction in the $\mathrm{Na}^{+}$and $\mathrm{Cl}^{-}$accumulation and the increase in the accumulation of $\mathrm{K}^{+}$and $\mathrm{Ca}^{2+}$. Therefore, it is suggested that GB application can be a promising approach to mitigate the salt stress effects in maize plants. However, field studies are direly needed before making a recommendation for the farmers. Moreover, additional studies should be conducted to understand how GB application mediates the hormonal cross talks under SS.

\section{Authors' Contributions}

Conceptualization: IK, MUC, M.F.S., MUH and ZD. Formal analysis: IK, MUC, M.F.S., MUH, R.S.J., B.A.A. and ZD. Investigation: ZD; Methodology: IK, MUC, ZD, MSF, E.A., Y.R., R.S.J and B.A.A. W ritingoriginal draft: IK, MUC, M.F.S., E.A., MUH and ZD. Writing - review and editing: M.S.F, E.A., Y.R., B.A.A., R.S.J. All authors read and approved the final manuscript.

\section{Acknowledgements}

Authors are thankful to Taif University Researchers Supporting Project number (TURSP-2020/65), Taif University, Taif, Saudi Arabia for providing the financial support and research facilities.

\section{Conflict of Interests}

The authors declare that there are no conflicts of interest related to this article. 


\section{References}

Aebi H (1984). Catalase in vitro. Methods in Enzymology 105:121-126.

https://doi.org/10.1016/s0076-6879(84)05016-3

Abbas W, Ashraf M, Akram NA (2010). Alleviation of salt-induced adverse effects in eggplant (Solanum melongena L.) by glycinebetaine and sugarbeet extracts. Scientia Horticulturae 125(3):188-195. https://doi.org/10.1016/j.scienta.2010.04.008

Abd-El-Mageed TA, Semida WM, Rady MM (2017). Moringa leaf extract as biostimulant improves water use efficiency, physio-biochemical attributes of squash plants under deficit irrigation. Agriculture and Water Management 193:46-54. https://doi.org/10.1016/j.agwat.2017.08.004

Ahmed N, Zhang Y, Li K, Zhou Y, Zhang M, Li M (2019). Exogenous application of glycine betaine improved water use efficiency in winter wheat (Triticum aestivum L.) via modulating photosynthetic efficiency and antioxidative capacity under conventional and limited irrigation conditions. Crop Journal 7(5):635-650. https://doi.org/10.1016/j.cj.2019.03.004

Alasvandyari F, Mahdavi B, Hosseini S (2017). Glycine betaine affects the antioxidant system and ion accumulation and reduces salinity-induced damage in safflower seedlings. Archives of Biological Sciences 69:139-147. https://doi.org/10.2298/ABS160216089A

Al-Ashkar, I, Alderfasi A, El-Hendawy S, Al-Suhaibani N, El-Kafafi S, Seleiman MF (2019). Detecting salt tolerance in doubled haploid wheat lines. Agronomy 9(4):211. https://doi.org/10.3390/agronomy9040211

Al-Ashkar I, Alderfasi A, Romdhane WB, Seleiman MF, El-Said RA, Al-Doss A (2020). Morphological and genetic diversity within salt tolerance detection in eighteen wheat genotypes. Plants 9(3):287. https://doi.org/10.3390/plants9030287

Ali S, Abbas ZM, Seleiman MF, Rizwan M, Yavas L, Alhammad BA, ... Kalderis D (2020). Glycine betaine accumulation, significance and interests for heavy metal tolerance in plants. Plants 7:896. https://doi.org/10.3390/plants9070896

Aamer M, Muhammad UH, Li Z, Abid A, Su Q, Liu Y, ... Huang G (2018). Foliar application of glycinebetaine (gb) alleviates the cadmium $(\mathrm{cd})$ toxicity in spinach through reducing cd uptake and improving the activity of antioxidant system. Applied Ecology and Environmental Research 1:7575-83. https://doi.org/10.15666/AEER/1606_75757583

Apel K, Hirt H (2004). Reactive oxygen species: metabolism, oxidative stress, and signal transduction. Annual Review of Plant Biology 55:373-399. https://doi.rog/10.1146/annurev.arplant.55.031903.141701

Ashraf M (2004). Some important physiological selection criteria for salt tolerance in plants. Functional Ecology of Plants 199(5):361-376. https://doi.org/10.1078/0367-2530-00165

Blum A (2017) Osmotic adjustment is a prime drought stress adaptive engine in support of plant production. Plant Cell and Environment 40(1):4-10. https://doi.org/10.1111/pce.12800

Bradford MM (1976). A rapid and sensitive method for the quantitation of microgram quantities of protein utilizing the principle of protein-dye binding. Analytical Biochemistry 72(1-2):248-254. https://doi.org/10.1006/abio.1976.9999

Caparrós P, Llanderal A, Hegarat E, Jiménez-Lao M, Lao MT (2020). Effects of exogenous application of osmotic adjustment substances on growth, pigment concentration, and physiological parameters of Dracaena sanderiana under different levels of salinity. Agronomy 10:125. https://doi.org/10.3390/agronomy10010125

Cirillo C, Rouphael Y, Caputo R, Raimondi G, Sifola MI, Pascale SD (2016). Effects of high salinity and the exogenous application of an osmolyte on growth, photosynthesis, and mineral composition in two ornamental shrubs. Journal of Horticulture Science and Biotechnology 91:14-22. https://doi.org/10.1080/14620316.2015.1110988

Demiral T, Turkan P (2004). Does exogenous glycinebetaine affect antioxidative system of rice seedlings under $\mathrm{NaCl}$ treatment? Journal of Plant Physiology 161(10):1089-1100. https://doi.org/10.1016/j.jplph.2004.03.009

Gadallah MAA (1999). Effects of proline and glycinebetaine on Vicia faba responses to salt stress. Biologia Plantarum 42(2):249-257. https://doi.org/10.1023/A:1002164719609

Habib N, Ashraf M, Ali Q, Perveen R (2012). Response of salt stressed okra (Abelmoschus esculentus Moench) plants to foliar-applied glycine betaine and glycine betaine containing sugar beet extract. South African Journal of Botany 83:151-158. https://doi.org/10.1016/j.sajb.2012.08.005

Hamilton PB, Van-Slyke DD (1943). Amino acid determination with ninhydrin. Journal of Biological Chemistry 150(1):231-250. https://doi.org/10.1039/AN9558000209 
Hasanuzzaman M, Alam MM, Rahman A, Hasanuzzaman M, Nahar K, Fujita M (2014). Exogenous proline and glycine betaine mediated upregulation of antioxidant defense and glyoxalase systems provides better protection against salt-induced oxidative stress in two rice (Oryza sativa L.) varieties. Biomed Research International 1:1-15. https://doi.org/10.1155/2014/757219

Homer DC, Pratt PF (1961). Methods of Analysis for soils, plants and waters. University of California, Davis.

Hoque MA, Banu MNA, Okuma E, Amako K, Nakamura Y, Shimoishi Y, Murata Y (2007). Exogenous proline and glycinebetaine increase $\mathrm{NaCl}$-induced ascorbateglutathione cycle enzyme activities, and proline improves salt tolerance more than glycinebetaine in tobacco Bright Yellow-2 suspension-cultured cells. Journal of Plant Physiology 164(11):1457-1468. https://doi.org/10.1016/j.jplph.2006.10.004

Hu L, Hu T, Zhang X, Pang X, Fu J (2012). Exogenous glycine betaine ameliorates the adverse effect of salt stress on perennial ryegrass. Journal of the American Society of Horticulture Science 137(1):38-46. https://doi.org/10.21273/JASHS.137.1.38

Jamil A, Riaz S, Ashraf M, Foolad MR (2011). Gene expression profiling of plants under salt stress. Critical Review in Plant Sciences 30(5):435-458. https://doi.org/10.1080/07352689.2011.605739

Jones J B, Case VW (1990). Sampling, handling, and analyzing plant tissue samples. Soil Test and Plant Analysis 3:389427. https://doi.org/10.2136/sssabookser3.3ed.c15

Lee DH, Kim YS, Lee CB (2001). The inductive responses of the antioxidant enzymes by salt stress in the rice (Oryza sativa L.). Journal of Plant Physiology 158(6):737-745. https://doi.org/10.1078/0176-1617-00174

Livia SS, Gabor K, Soltan S (2002). Effect of salt stress on free amino acid and polyamine content in cereal. Acta Biologica Szegediensis 46(3-4):73-75.

Lichtenthaler HK (1987). Chlorophylls and carotenoids: Pigments of photosynthetic biomembrane. Methods in Enzymology 148:350-352. https://doi.org/10.1016/0076-6879(87)48036-1

Kaya C, O Sönmez, S Aydemir M Dikilitaş (2013). Mitigation effects of glycinebetaine on oxidative stress and some key growth parameters of maize exposed to salt stress. Turkish Journal Agriculture and Forestry 37(2):188-194. https://doi.org/10.3906/tar-1205-18

Mahmood T, Ashraf M, Shahbaz M (2009) Does exogenous application of glycinebetaine as a pre-sowing seed treatment improve growth and regulate some key physiological attributes in wheat plants grown under water deficit conditions? Pakistan Journal of Botany 41(3):1291-1302.

Ma QQ, Wang W, Li YH, Li DQ, Zou Q (2006). Alleviation of photoinhibition in drought-stressed wheat (Triticum aestivum) by foliar-applied glycinebetaine. Journal of Plant Physiology 163(2):165-175. https://doi.org/10.1016/j.jplph.2005.04.023

Mansour MMF (1998). Protection of plasma membrane of onion epidermal cells by glycinebetaine and proline against $\mathrm{NaCl}$ stress. Plant Physiology and Biochemistry 36(10):767-772. https://doi.org/10.1016/S0981-9428(98)80028-4

Maxwell K, Johnson GN (2000). Chlorophyll fluorescence: a practical guide. Journal of Experimental Botany 51(345):659-668. https://doi.org/10.1093/jexbot/51.345.659

Mbarki S, Sytar O, Cerda A, Zivcak M, Rastogi A, He X, ... Brestic C (2018). Strategies to mitigate the salt stress effects on photosynthetic apparatus and productivity of crop plants. In: Salinity Responses and Tolerance in Plants 1:85136. https://doi.org/10.1007/978-3-319-75671-4_4

Meloni DA, Martínez CA (2009). Glycinebetaine improves salt tolerance in vinal (Prosopis ruscifolia Griesbach) seedlings. Brazilian Journal of Plant Physiology 21(3):233-241. http://dx.doi.org/10.1590/S1677-04202009000300007

Mittler R (2002). Oxidative stress, antioxidants and stress tolerance. Trends in Plant Science 7(9):405-410. https://doi.org/10.1016/s1360-1385(02)02312-9

Mostofa MG, Fujita M (2013). Salicylic acid alleviates copper toxicity in rice seedlings by up-regulating antioxidative and glyoxalase systems. Ecotoxicology 22(6):959-973. https://doi.org/10.1007/s10646-013-1073-X

Moustakas M, Sperdouli I, Kouna T, Antonopoulou C, Therios I (2011). Exogenous proline induces soluble sugar accumulation and alleviates drought stress effects on photosystem II functioning of Arabidopsis thaliana leaves. Plant Growth Regulation 65(2):315-321. https://doi.org/10.1007/s10725-011-9604-Z

Mukherjee SP, Choudhuri MA (1983). Implications of water stress induced changes in the levels of endogenous ascorbic acid and hydrogen peroxide in Vigna seedlings. Physiology of Plants 58:166-170.

https://doi.org/10.1111/j.1399-3054.1983.tb04162.x 
Munns R, Tester M (2008). Mechanisms of salinity tolerance. Annual Review of Plant Biology 59:651-681. https://doi.org/10.1146/annurev.arplant.59.032607.092911

Nawaz K, Ashraf M (2007). Improvement in salt tolerance of maize by exogenous application of glycinebetaine: growth and water relations. Pakistan Journal of Botany 39(5):1647-1653.

Radi R (2018). Oxygen radicals, nitric oxide, and peroxynitrite: Redox pathways in molecular medicine. Proceedings of the National Academy of Science, USA 115:5839-5848. https://doi.org/10.1073/pnas.1804932115

Rady MO, Semida VM, Abd-El-Mageed T, Hemida KA, Rady MM (2018). Up-regulation of antioxidative defense systems by glycine betaine foliar application in onion plants confer tolerance to salinity stress. Scientia Horticulturae 240:614-622. https://doi.org/10.1016/j.scienta.2018.06.069

Rahman MS, Miyake H, Takeoka Y (2002). Effects of exogenous glycinebetaine on growth and ultrastructure of saltstressed rice seedlings (Oryza sativa L.). Plant Production Science 5(1):33-44. https://doi.org/10.1626/pps.5.33

Ranganayakulu GS, Veeranagamallaiah G, Sudhakar C (2013). Effect of salt stress on osmolyte accumulation in two groundnut cultivars (Arachis hypogaea L.) with contrasting salt tolerance. African Journal of Plant Science 7(12):586-592. https://doi.org/10.5897/AJPS11.063

Rao KM, Sresty TVS (2000). Antioxidative parameters in the seedlings of pigeonpea (Cajanus cajan L.) Millspaugh) in response to Zn and Ni stresses. Plant Science 157(1):113-128. https://doi.org/10.1016/s0168-9452(00)00273-9

Raza SH, Athar HR, Ashraf M, Hameed A (2007). Glycinebetaine-induced modulation of antioxidant enzymes activities and ion accumulation in two wheat cultivars differing in salt tolerance. Environmental and Experimental Botany 60(3):368-376. https://doi.org/10.1016/j.envexpbot.2006.12.009

Sakamoto A, Murata N (2002). The role of glycine betaine in the protection of plants from stress: clues from transgenic plants. Plant Cell and Environment 25(2):163-171. https://doi.org/10.1046/j.0016-8025.2001.00790.x

Sakr MT, El-Sarkassy NM, PFuller M (2012). Osmoregulators proline and glycine betaine counteract salinity stress in canola. Agronomy for Sustainable Development 32(3):747-754. https://doi.org/10.1007/s13593-011-0076-3

Semida WM, Abd El-mageed TA, Howladar SM, Rady MM (2016). Foliar-applied a-tocopherol enhances salt-tolerance in onion plants by improving antioxidant defense system. Australian Journal of Crop Sciences 10(7):1030-1039. https://doi.org/10.21475/ajcs.2016.10.07.p7712

Semida WM, El-Mageed TAA, Mohamed SE, El-Sawah NA (201)7. Combined effect of deficit irrigation and foliarapplied salicylic acid on physiological responses, yield, and water-use efficiency of onion plants in saline calcareous soil. Archives of Agronomy and Soil Science 63(9):1227-1239. https://doi.org/10.1080/03650340.2016.1264579

Semida WM, Taha RS, Abdelhamid MT, Rady MM (2014). Foliar-applied $\alpha$-tocopherol enhances salt-tolerance in Vicia faba L. plants grown under saline conditions. South African Journal of Botany 95:24-31. https://doi.org/10.1016/j.sajb.2014.08.005

Shrivastava, P, Kumar R. 2015. Soil salinity: a serious environmental issue and plant growth promoting bacteria as one of the tools for its alleviation. Saudi Journal of Biological Sciences 22(2):123-131. https://doi.org/10.1016/j.sjbs.2014.12.001

Seleiman MF, Al-Shuaibani N, Ali N, Akmal M, Alotaibi M, Rafey Y, ... Battaglia ML (2021). Drought stress impacts on plants and different approaches to alleviate its adverse effects. Plants 10(2):259. https://doi.org/10.3390/plants10020259

Seleiman MF, Kheir AMS (2018). Saline soil properties, quality and productivity of wheat grown with bagasse ash and $\begin{array}{llll}\text { thiourea in different } & \text { 193:538-546. }\end{array}$ https://doi.org/10.1016/j.chemosphere.2017.11.053

Seleiman MF, Santanen A, Jaakkola S, Ekholm P, Hartikainen H, Stoddard FL, Mäkelä PS (2013). Biomass yield and quality of bioenergy crops grown with synthetic and organic fertilizers. Biomass Bioenergy 59:477-485. https://doi.org/10.1016/j.biombioe.2013.07.021

Seleiman MF, Semida WM, Rady MM, Mohammad GF, Hemida KA, Alhammad BA, Hassan MM, Shami A (2020). Sequential application of antioxidants rectifies ion imbalance and strengthens antioxidant systems in salt-stressed cucumber. Plants 9(12):1783. https://doi.org/10.3390/plants9121783

Seleiman M (2019). Use of plant nutrients in improving abiotic stress tolerance in wheat. In: Hasanuzzaman M, Nahar K, Hossain MA (Eds). Wheat Production in Changing Environments. Springer, Singapore, pp 481-495. https://doi.org/10.1007/978-981-13-6883-7_19 
Slama I, xAbdelly A, Bouchereau A, Flowers T, Savoure A (2015). Diversity, distribution and roles of osmoprotective compounds accumulated in halophytes under abiotic stress. Annals of Botany 115:433-447. https://doi.org/10.1093/aob/mcu239

Steel RGD, Torrie JH, Dickey D (1997). Principles and Procedures of statistics: a biometric approach. $3^{\text {rd }}$ edition, McGraw-Hill Book Co., New York, USA pp 663-666.

Taamalli WL Youssef NB, Miled DDB, Zarrouk M (2004). Lipid breakdown in sunflower (Helianthus annuus L.) seeds during post germinative growth under salt-stress. Rivista Italian Delle Gostanze Grasse 81:90-97.

Taha RS, Seleiman MF, Alotaibi M, Alhammad BA, Rady MM, Mahdi AHA (2020). Exogenous potassium treatments elevate salt tolerance and performances of Glycine max L. by boosting antioxidant defense system under actual saline field conditions. Agronomy 10(11):1741. https://doi.org/10.3390/agronomy10111741

Taha RS, Seleiman MF, Alhammad BA, Alkahtani J, Alwahibi MS, Mahdi AH (2021). Activated Yeast extract enhances growth, anatomical structure, and productivity of Lupinus termis L. plants under actual salinity conditions. Agronomy 11(1):74. https://doi.org/10.3390/agronomy11010074

Velikova V, Yordanov I, Edreva A (2000) Oxidative stress and some antioxidant systems in acid rain-treated bean plants: protective role of exogenous polyamines. Plant Science 151:59-66. https://doi.org/10.1016/S0168-9452(99)00197-1

Yildirim E, Ekinci M, Turan M, Dursun A, Kul R, Parlakova F (2015). Roles of glycine betaine in mitigating deleterious effect of salt stress on lettuce (Lactuca sativa L.). Archives of Agronomy and Soil Science 61(12):1673-1689. https://doi.org/10.1080/03650340.2015.1030611

Zhu JK (2002). Salt and drought stress signal transduction in plants. Annual Review of Plant Biology 53(1):247-273. https://doi.org/10.1146/annurev.arplant.53.091401.143329

Zhang XZ (1992) The measurement and mechanism of lipid peroxidation and SOD, POD and CAT activities in biological system. Research Methods of Crop Physiology 208-222.
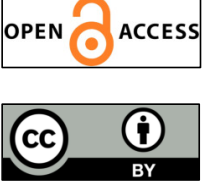

The journal offers free, immediate, and unrestricted access to peer-reviewed research and scholarly work. Users are allowed to read, download, copy, distribute, print, search, or link to the full texts of the articles, or use them for any other lawful purpose, without asking prior permission from the publisher or the author.

License - Articles published in Notulae Botanicae Horti Agrobotanici Cluj-Napoca are Open-Access, distributed under the terms and conditions of the Creative Commons Attribution (CC BY 4.0) License.

(c) Articles by the authors; UASVM, Cluj-Napoca, Romania. The journal allows the author(s) to hold the copyright/to retain publishing rights without restriction. 